\title{
Female Violent Extremist Prisoners (VEPs) Guidance
}

\author{
Kusmiyanti', D E E Saputra ${ }^{2}$ \\ 1. Politeknik Ilmu Pemasyarakatan ${ }^{2}$ Deputy Director of International Partnership, Directorate \\ General of Corrections

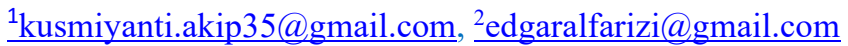

\begin{abstract}
Violent Extremist Offenders (VEOs) in Indonesia has increased for years. In 2018, the numbers of Violent Extremist Prisoners (VEPs) in Indonesia are 551 persons and keep increasing in 2019. Based on the data from August 2019, the numbers of VEPs are about 592 persons. The VEPs are all spread in prisons around Indonesia. Not only men who become VEPs, but there are also 4 female VEPs. Female VEPs are collected in Tangerang Class II Female Prison, Bandung Class II Female Prison and Malang Clas II Female Prison. There are so many questions on how women become a part of terrorist offenders. Remembering on some of terror case that happened does involve women even a family. Mother's role that should have been strong in taking care of their family has become interesting. This research will raise an issue of how female VEPs can engage in VEOs and how the guidance is done in prisons? This research aims to determine the guidance conducted by prison and female VEPs involvement in VEOs. This research was conducted in Tangerang Class II Female Prison, Bandung Class IIA Female Prison and Malang Clas II Female Prison. This research using a qualitative approach and was conducted in August 2019. Data was collected by observation, interview and document study techniques then processed and analyzed qualitatively. The results of this research indicate that no specific guidance has been conducted for female VEPs. Correctional officers should be given a special training regarding female VEPs.
\end{abstract}

Keywords: Guidance, Violent Extremist Prisoners (VEPS), Women.

\section{INTRODUCTION}

Based on Law No. 5 of 2018 concerningthe changes of Law No. 15 of 2003 about the enactment of Government Regulations in Lieu of Law No. 1 of 2002 about Violent Extremist Offenders (VEOs) eradication to be Law mention that Terrorism is an act of violence or a threat of violence that can create a terror situation or fear widely, which can cause mass casualties, and/or can cause damage against vital strategic objects, environment, public facilities, or international facilities with ideological, political, or threat interference motives. VEOs can break the unity and integrity of a nation, undermine the defense system, damage the economy and violate human rights.

VEOs in Indonesia from year to year have increased. The following is a series of data on acts of terror over the past ten years in Indonesia according to CNN Indonesia:

\begin{tabular}{ll}
\hline 1 & Shooting in Gemblengan Police Station 2012 \\
\hline 2 & Grenade throwing in Gledak 2012 \\
\hline 3 & Suicide Bombing in Mapolresta Solo 2016 \\
\hline
\end{tabular}




\begin{tabular}{ll}
\hline 4 & Kampung Melayu Pot Bombing 2017 \\
\hline 5 & Church Explotion in Surabaya 2018 \\
\hline 6 & Attacks in Mapolda Riau 2018 \\
\hline 7 & Suicide Bombing in Mapolresta Medan 2019 \\
\hline
\end{tabular}

From several acts of terror above, based on Indonesia Police records quoted by (Detiknews, 2018) mention that in 2017 a total of 176 terrorist, and in 2018 have increased to 396 terrorist which has been captured and secured by the Indonesian Police. Based on the data from Directorate General of Corrections, in 2018 the numbers of VEPs in Indonesia are 551 people and have increased in 2019. The data from August 2019, the numbers of VEPs are 592 people (https://smslap.ditjenpas.go.id). The VEPs are all spread in every prison around Indonesia, for example in Nusakambangan Island and Gunung Sindur Prison. VEOs are not only consisting male VEPs but there are also consisting Female and Child VEPs. In quantitative data, there are about 4 VEPs in Indonesia. Female VEPs are collected in Tangerang Clas I Female Prison, Bandung Clas IIA Female Prison, Medan Clas IIA Female Prison, Malang Clas IIA Female Prison. From those 4 Female VEPs, 3 of them were from the Bintara pot group.

All forms of efforts to deal with VEOs have been carried out by the Law Enforcement Officers in combating in Indonesia. Not only from Early Warning Terrorism and operation/surveillance that implemented by the Republic of Indonesia police, especially Detasemen 88 Anti-terror Republic of Indonesia, State Intelligence Agency, National Counterterrorism Agency, and Strategic Agency of the Indonesia National Armed Forces but the role of Directorate General of Corrections on post-operative treatment which is VEPs guidance inside Prison. VEPs guidance implemented based on Directorate General of Corrections Ministry of Law and Human Rights of Indonesia decision No: PAS - 24.OT.02.02 of 2019 concerningTechnical Instructions towards High Risk Prisoners Guidance in Special Prison. (PP, Ditjen PP Kemenkumham Republik Indonesia, 2015)

The amount of VEPs certainly raises its own problem for prison because VEPs have their own characteristic. The characteristics of VEPs have a tendency to shut themselves and not cooperative. VEPs have also a potency to spread radicalism to other prisoners and officers. Therefore, the guidance towards VEPs has to be different from the guidance towards other prisoners. Based on the introduction, the research question is how is the implementation of Female VEPs guidance?

\section{RESEARCH METHOD}

The research method that we use is qualitative research method, where theory is not the main starting point. The data that has been obtained in the field will be combined with theory in order to develop a comprehensive interpretation in general. According to John W. Creswell "qualitative research is an inquiry of understanding based on distinct methodological traditions of inquiry that explore social or human problem. The researcher build a complex, holistic picture, analyze words, reports detailed views of informants, and conducts the study in natural setting. The research disposition is descriptive research which is intended to describe a phenomenon by examining it in a structured manner, prioritizing objectivity, and doing it carefully.

\section{RESULTS AND DISCUSSION}


According tp P.A.F Lamintang, imprisonment is a criminal in the form of freedom of movement limitation of a convicted person by locking them up in prison with the obligation to obey all applicable rules and regulations in prison that are associated with an action if the violate those regulations. According to R.A Koesnoen, among several kinds of crimes, the important thing is the crime of missing independence carried out in prison. Because, by the crime of missing independence the prisoner must be in prison for certain period of time until the state has full opportunity to fix it.

According to Djisman Samosir, imprisonment is one of the main crimes that limit freedom of movement of prisoners and their implementation by locking up the prisoners in prison. With locking prisoners up in prison contained intentions that other people are not affected by the prisoners trait; so that the officers can easily guide the prisoner; also so that the prisoners not repeat their action after being released.

The change from Imprisonment to Corrections was started by DR. Saharjo, S.H. that was served as the Minister of Justice at the time. On Juli 5, 1963 in the Republic of Indonesia State Palace in the awarding of Honoris Causa Doctorate Degree in Law with his speech "Banyan Tree of Protection"; which stated that the purpose from imprisonment is "Correctional" and also express conception about the national law which he described as "Banyan Tree" to symbolize "the function of Law is to providing guidance to the society so that the noble ideals of the nation are achieved and maintained. DR, Sahardjo, S.H. about them who have been locked up in prison was very noble "every person is human and must be treated as one even though he was lost once, it must be shown to a prisoner that they are seen and needed as a human being".

The idea about correctional reached its peak on April 27, 1964 at the National Imprisonment Conference in Grand Hotel Lembang. At the Lembang Conference basic principles concerning the treatment of prisoners was formulated. Ten (10) correctional principles which was agreed as a guiding guidance for prisoners in Indonesia as follows:

1. Protect and provide life supplies so that they can carry out their role as good and useful citizens.

2. Imprisonment is not an act of state revenge.

3. Give guidance not torture so that they regret what they did.

4. The state has no right to make them worse than before they were convicted.

5. During the loss of freedom of movement, prisoners and protégé must be introduced and must not be exiled from society.

6. Work given to prisoners and protégé should not be just for filling time, and also they shouldn't be given work to fulfill the needs or interest of the country at any time.

7. Guidance and education that given for prisoners and protégé must be based on Pancasila.

8. Prisoners and protégé as lost people are human and the must be treated as one.

9. Prisoners and protégé only convicted of missing freedom as one of their sufferings.

10. Provided and fostered facilities that can support rehabilitative, corrective and educative functions in the correctional system.

Correctional as a purpose where criminal must be free from liberal individualism views and therefore "Correctional" as a criminal purpose is interpreted as "Restoratin of the unity of life and livelihood relationships" that essential, what happened between the individual lawbreaker concerned with the community and their living environment, under the unity of relationship with God Almighty with Pancasila (Social Re-integration).

Correctional systems have a guidance strategy especially concerning process and guiding program. Guiding process described as a stage of guiding that started from intramural guiding stage and move gradually, in accordance with the progress of the results of guiding, towards guidance that is implemented in the middle of society (extramural) this guiding stages are 
intended to be eliminated even the slightest destructive impact of imprisonment in the form of stigmatization, prisonitation and recidivism. In its implementation, this stage of the guidance process requires community participation, support and control, which significantly determines the success of the process itself.

\begin{tabular}{lll}
\hline The guiding stages are as follows: & $\begin{array}{l}\text { 1. Admission orientation. } \\
\text { 2. }\end{array}$ & $\begin{array}{l}\text { Determination of the initial program } \\
\text { through the trial }\end{array}$ \\
& 3. $\begin{array}{l}\text { Implementation of the start and } \\
\text { evaluation program }\end{array}$ \\
\hline $\begin{array}{l}\text { The implementation of correctional } \\
\text { processes is regulated in Government }\end{array}$ & $\begin{array}{l}\text { 1. } \text { Early Stage Guidance } \\
\text { Advanced Guidance }\end{array}$ \\
$\begin{array}{l}\text { Regulation No. } 31 \text { of } 1999 \text { concerning } \\
\text { the fostering and guidance of }\end{array}$ & 3. Final Stage Guidance \\
$\begin{array}{l}\text { Correctional Prisoners. The guiding } \\
\text { phase includes: }\end{array}$
\end{tabular}

VEPs placement in prison is a duty of the correctional officers to guide them. In accordance with the concept of correctional which focuses on prisoner guidance. No detention and revenge against prisoners. In accordance with the Decree of the Head of the Directorate of Corrections Number K.P.10.13 / 3/1, February 8, 1985, determine a conception concerning correctional as atheurapeuntie process i.e. where prisoners first time in prison without a state of harmony with society, have a negative relations with society. So far, prisoners are then guided with other elements in society, so in the end prisoners with the surrounding community can be in harmony.

Law No. 12 of 1995 concerning Correctional that prison as a place to guide prisoners has a purpose and function to guide prisoners so that they are aware of their mistakes and prepare for correctional assistance that can be integrated with the community, so that when prisoners are free can be re-accepted by the community

Guidance that implemented in prisons divided into two: personality guidance and vocational guidance. Personality guidance is related to restoring prisoners' life relationship with the society. Personality guidance included religious awareness guidance, national and state awareness guidance, intellectual ability guidance, legal awareness guidance. While vocational guidance closely related to the restoration of livelihood, the prisoner's livelihood relationship with the society that is the prisoner's relationship with their work. Vocational guidance included providing programs such as skills to support independent business, and also skills to support small industrial businesses.

As prisoners, they all must be guided that is conducted by prison. The guidance program that was conducted was apparently not followed by the VEPs. VEPs are very selective in choosing the activity that was conducted in prison. It is not easy for the officers in guiding them. The things that have been damage in VEPs are ideology, which is the one to be repaired. It is hard to change ideology because they brain have been brainwashed. The guidance towards VEPs should have been different than any other crime prisoners. Special guidance must be given to the VEPs. The treatment towards VEPs must eliminate the chance for them to engage in any terrorism act both inside and outside prison.

This is apparently not the case for VEPs. When these VEPs first enter prison, they will enter into a period of admission orientation. During the admission orientation period, they will be introduced to the prison environment as well as their rights and obligations as inmates. After completing the admission orientation period, the inmates will be sent to their blocks. Despite 
VEPs are categorized as "high-risk inmates" and undoubtedly dangerous, however, they will not be receiving any special treatment. There are some possibilities for the other inmates to get influenced by VEPs when they are being placed in the same cells. Based on the observations from researchers, these VEPs are sharing their blocks and rooms with other inmates. For example, there are one room with 14 inmates and another room with 8 inmates. Several concerns arise when the VEPs are being transferred to penitentiary and being placed together with other regular inmates.

In this regard, correctional officers play a significant role in providing guidance for inmates, in which they are obligated to carry out various roles and have the following characteristics: (a) Teacher, means that the officers are obligated to have knowledge about correctional system, psychology, and good attitudes, (b) Parent, means that the officers are able to provide protection and guidance, able to handle the problems calmly, trt the inmates fairly, behave accordingly, etc. (c) Guard, means that the officers are physically good and strong, and have a good selfdefense skills. In addition to deal with physical assault incident within the prison, it also aims to instill a sense of high self-esteem and high mental endurance.

RAND Corporation defines deradicalization as "the process of changing an individual beliefs system, rejecting the extremist ideology, and embracing mainstream values". After looking the explanation about "the basic requirements" for correctional officers above, indeed, the officers carry the great burden of responsibility on their shoulders, likewise when they are providing guidance for the VEPs. There are some differences in providing guidance for regular inmates and VEPs. For example, the officers are not allowed to interact with VEPs and discussing their cases, as well as doing the intense communication. When the officers interact and talk to them intensely, the chance for the officers to be affected by radicalism idea is quite high. In fact, there are several cases in which the officers eventually affected and helped the VEPs instead.

The officers are expected to have special expertise in guiding VEPs by using psychological approach in doing so. One of VEP named DY, appeared as the one and only woman who totally ready to become suicide bomber. When she was transferred to the penitentiary for the first time, she was not able to open up to the officers and other inmates and she kept herself isolated. The officers were taking special approach in tackling this case, whereby the officers chose not to discuss her cases until she enters the prison. The officers were slowly giving the understanding to DY by changing her mindset, especially when she was being moved along with her baby. All actions that have been taken by the officers were executed slowly but surely. In this case, the officers were attempting to bring her maternal side out and made her aware about her role as a mother who will raise her own children. Apparently, this method was worked out in changing herself as well as her attitude. DY began to mingle with other inmates and participated in gymnastic activities, although she still refused to participate in personality guidance. The officers did not completely conduct religious guidance since it is quite sensitive to talk about this issue.

At the beginning, DY was also refused to participate in vocational guidance, but in the end, she was willing to do so, and she started to learn how to knit. After serving her sentence for 2 years, she was showing her great progress. Besides, BNPT was likewise contributed in providing guidance for VEPs once in a year. In doing so, BNPT was bringing psychologists and lecturers from the State Islamic University. Their guidance only lasts for approximately 4 hours. The guidance plays an important role in changing DY's self despite being done for 4 hours only. BNPT's guidance should be done at least every month because it will give a better result. The guiders are the right people since they have expertise in their field and the most importantly, 
they are psychologists and professionals which have religious knowledge. The only and important things that needs to be corrected is VEPs' mindset.

Mindset shift process for VEPs requires a special mechanism and it is not recommended for doing so without involving psychologists because it is highly dangerous and risky. The lack of knowledge becomes a significant cause of the officers' vulnerability to radicalism. Hence, the training for officers is necessarily needed to address this issue. Besides, BNPT should begin to create special guidance mechanism for the VEPs. Terrorism crime keeps increasing every year. If we look at the information about terrorism in Indonesia, the major reason behind those terror acts is economic condition. As we all know, Indonesia has been dealing with poverty issue ever since a long time ago and it becomes one of Indonesia's main concern. According to social theory (creative deprivation theory), there is a correlation between poverty and terrorism. Poverty can be seen as social injustice and hence, terrorism emerged as an expression against social injustice.

A crime can be caused by the influence of the group on individuals as well as their surroundings. This is purely sociological approach which focused on social relations, frequencies, and intensity of associations. Here are some postulates of differential theory according to Sutherland:

\begin{tabular}{ll}
\hline 1 & Criminal behavior is learned \\
\hline 2 & $\begin{array}{l}\text { Criminal behavior is learned in interaction with other persons in a process of } \\
\text { communication }\end{array}$ \\
\hline 3 & $\begin{array}{l}\text { The principal part of the learning of criminal behavior occurs within intimate } \\
\text { personal groups }\end{array}$ \\
\hline 4 & $\begin{array}{l}\text { When criminal behavior is learned, teh learning includes (a) techniques of } \\
\text { committing the crime, which are sometimes very complicated, some of } \\
\text { committing the crime, which are sometimes very complicated, sometimes very } \\
\text { simple; (b) the specific direction of motives, drives, rationalizations, and } \\
\text { attitudes }\end{array}$ \\
\hline 5 & $\begin{array}{l}\text { The specific direction of the motives and drives is learned from definitions of } \\
\text { the legal codes as favorable or unfavorable }\end{array}$ \\
\hline 6 & $\begin{array}{l}\text { A person becomes deliquent because of an axcess of definitions favorable to } \\
\text { violation of law over definitions unfavorable to violation of law }\end{array}$ \\
\hline 7 & Differential association may very in frequency, duration, priority, and intensity \\
\hline 8 & $\begin{array}{l}\text { The process of learning criminal behavior by association with criminal and } \\
\text { anti-criminal patterns involves all of the mechanisms that are involved in any } \\
\text { other learning }\end{array}$ \\
\hline
\end{tabular}

While criminal behavior is an expression of general needs and values, it is not explained by those general needs and values since non-criminal behavior is an expression of the same needs and values (Sutherland, 1978:80-82)

Radicalization is not as simple as it seems, there is a process in which radicalization can turn into terror and it takes a long time. In fact, there are some people who need at least 10 years to become terrorist. We need to highlight the most essential part, in which their biggest motives in becoming a terrorist is economic problems. Hence, the correctional officers play an important role in guiding VEPs. VEPs should be given an entrepreneurial training so that they will be able to get a proper job or run their own business after their release. Social control theory by Travis Hirschi (1969) explains that there are four elements of social bonds:

1 Attachment is defined as a person's interest in another person (parents) or a school institution can prevent or hinder the person to commit a crime. 


\begin{tabular}{ll}
\hline 2 & $\begin{array}{l}\text { Involvement means that the frequency of a person's activities will minimize the } \\
\text { tendency of the person to commit a crime. }\end{array}$ \\
\hline 3 & $\begin{array}{l}\text { Commitment defined as a person's investation in society, among others in the form } \\
\text { of education, a good reputation, and the progress in the entrepreneurship sector. }\end{array}$ \\
\hline 4 & $\begin{array}{l}\text { Belief is an element that embodies a person's recognition of good and equitable } \\
\text { norms in society. (William \& McShanne, 1988) }\end{array}$ \\
\hline
\end{tabular}

When VEPs are bring released, there are many problems that they will face. One of the problem is stigmatization from society. Society still see that when VEPs are free, they will remain as terrorist. Society reject them, stay away from them, and don't want to interact with them. The role of society that still reject ex-VEPs will affect ex-VEPs behavior. Very possible for ex-VEPs to think commit a similar crime. Finally, the VEPs recidivists are emerged. Like labeling theory according to Schrag (1971: 89-91) concludes the basic assumptions of labeling theory as follows:

\begin{tabular}{ll}
\hline 1 & There is no single act that happen by itself can be categorize as criminal \\
\hline 2 & $\begin{array}{l}\text { The formulation or limits regarding crime and criminals are forced in accordance with } \\
\text { the interests of those who have power. }\end{array}$ \\
\hline 3 & $\begin{array}{l}\text { A person becomes a criminal not because he violated the law, but because he is } \\
\text { determined by the authorities. }\end{array}$ \\
\hline 5 & $\begin{array}{l}\text { Regarding to the fact that everyone can do good and bad things, does not mean that } \\
\text { they can be categorized into two parts: criminal and non-criminal. }\end{array}$ \\
\hline 6 & The act of arrest is the beginning of the labelling process \\
\hline 7 & $\begin{array}{l}\text { Arrest and decision making in the criminal justice system is a function of the } \\
\text { perpetrators / criminals as opponent from characteristics of the violation. }\end{array}$ \\
\hline 8 & $\begin{array}{l}\text { The criminal justice system is formed based on the perspective of free will that allows } \\
\text { judgment and rejection of those who are seen as criminals. }\end{array}$ \\
\hline 9 & $\begin{array}{l}\text { Labeling is a process that will create identification with images as deviants and } \\
\text { subcultures and produce rejection of the rejector (Hagan, 1989: 453-545). }\end{array}$ \\
\hline
\end{tabular}

Guidance that should be done by correctional officers is vocational guidance and personality guidance. Vocational guidance provided in prison is a form of work activities that usually have entrepreneurship and skills training. The purpose of vocational guidance is to provide skills so that when they are free, they can open their own businesses.

What we can see is what is visible, but we can see what is delivered and done. The initial process that we can do is disengagement. His/her life is sometimes abnormal, so at a certain point, terrorists in prison are forced to be disengagement. Treatment from outside that can help terrorists to repent, but when they return to the society, they don't want to accept it because they are afraid and can be seen from the name of the terrorist. Guidance has to be comprehensive. We see that cases in Indonesia, stigmatization are still strong then the mass media too. This causes ex-VEPs to be hampered in repentance. Economic empowerment is important for the return of prisoners in the middle of society. Radicalization is a process that is carried out continuously for the ideology. Pull factors and push factors become important to return them in the middle of society.

Officer firmness become an important thing, on December 13, 2017 has moved from Mako Brimob. Vocational guidance that was done, VEPs are in the same room with general 
prisoners so VEPs doesn't shut themselves from other people. The type of guidance that was done by BNPT every year are to identified the starting point, re-education by inviting psychologist and lecturer from UIN, thus are already have been many changes. Obedient with her husband is the first stage to do VEOs, she has to change her mindset, there is no psychologist for them while the husband is locked up in Tangerang Clas I Prison.

\section{CONCLUSIONS}

Based on description above, the writer can conclude that there has been no specific guidance done for female VEPs. Guidance that is done is still the same as guidance for other case inmates. Special guidance for VEPs is necessary. Moreover, female VEPs who have a role as mothers. Has a very big responsibility and role in educating their children. Correctional officers must be given special training to treat them. Correctional officers must be given special training to treat them. Given the increasing number of terrorism crimes. These women are very weak and very easily influenced by her husband. These female VEPs are involved in becoming terrorists because of their obedience to their husbands. They didn't see the orders as good or bad

\section{REFERENCES}

[1] Romli Atmasasmita, "Teori Kriminologi, Refika Aditama, Bandung:2013.

[2] Sutherland, Edwin H. 1978. Criminology. Edisi kesepuluh. J.B. Lippincot Company.

[3] William III, Frank P., \& Mc Shane Marilyn D. 1988. Criminological Theory. Prentice Hall.

[4] Koesnoen, R.A., Susunan Pidana Dalam Negara Sosialis Indonesia, Sumur, Bandung, 1964

[5] Surjobroto, Baharudin, Suatu Tinjauan Tentang Sistem Pemasyarakatan, Departemen Kehakiman RI, Jakarta, 1991.

[6] Creswell, John W, Research Design, Pendekatan Metode Kualitatif, Kuantitatif dan Campuran Edisi Keempat, (Yogyakarta: Pustaka Pelajar, 2016)

[7] C. Djisman Samosir. Sekelumit Tentang Penologi dan Pemasyarakatan (Bandung:Nuansa Aulia, 2009)

[8] P.A.F. Lamintang. Hukum Penitensier Indonesia. (Bandung:Armico,1984)

[9] http://smslap.ditjenpas.go.id/public/grl/current/monthly/year/2018/month/12 (Diakses pada tanggal 18 September 2019)

[10] http://smslap.ditjenpas.go.id/public/grl/current/monthly/year/2019/month/8 (Diakses pada tanggal 18 september 2019)

[11] Undang-Undang Nomor 12 Tahun 1995 tentang Pemasyarakatan

[12] Keputusan Direktur Jenderal Pemasyarakatan Kementerian Hukum dan Hak Asasi Manusia Republik Indonesia Nomor PAS-172.PK.01.06.01 Tahun 2015 tentang Standar Pembinaan Narapidana Teroris 
